actively to discourage these practices.

- Those organizations with computer records are best able to track price changes in library materials and provide information to customers or users. It is essential to provide such information to libraries for use in their budget justification and planning for collection development.

- As European vendors and libraries automate their processes, they need to be made aware of the requirements of North American libraries for library materials price data.

The first Nijhoff Study Grant provided an opportunity for Lynden to follow up on a proposal made in 1977 at a LIBER (Ligue des Bibliothèques Européenes de Recherche) meeting in Leiden. It was agreed at that meeting that LIBER should try to publish national indexes for academic books. It was suggested that indexes be produced from four countries which together produce the principal part of European publishing output: Great Britain, France, Germany, and the Netherlands. It was also agreed that indexes conform to a standard defined by LIBER which included the use of the
UNESCO classification for subject headings and total number of publications per subject heading. Although Great Britain continued to produce its Academic Book Price Index (Centre for Library and Information Management), no other country had produced one by 1986 . Therefore, the Lynden study may assist in the renewal of the earlier effort by identifying the organizations which can produce price data and the individuals who have both the expertise and interest in the production of such indexes. It is clear that any future effort will require cooperation among vendors, librarians, and book trade association officials.

Lynden's research was made possible through the first annual grant from the Martinus Nijhoff Company, The Hague, The Netherlands, in a program advertised by ACRL's Western European Specialists Section. Funds will be given annually to encourage the study of some aspect of the acquisition, organization, or use of library materials from or relating to Western Europe.-WESS Newsletter.

\title{
ACRL actions, January 1987
}

\section{Highlights of the Midwinter meetings of the ACRL Board of Directors.}

$\mathbf{T}$ he Board of Directors of the Association of College and Research Libraries met twice during the ALA Midwinter Meeting in Chicago, Illinois: on Sunday, January 18, 1987, and Tuesday, January $20,1987$.

\section{ALA Divisions}

The Board made a recommendation to the ALA Committee on Program Evaluation and Support (COPES) that it include in the proposed Policies of the American Library Association in Relation to its Divisions a policy permitting divisions to earn interest. To be eligible to participate in the interest- generating program, a division would have to show at the beginning of two consecutive years a fund balance equal to at least $50 \%$ of the previous year's expenses. COPES will be examining the proposed policy further and will submit a final draft to ALA Council at the Midwinter Meeting 1988.

The Board also recommended to COPES that charges to divisions for new services be established only after mutual discussion and agreement between ALA and its divisions; and that a committee of division officers meet with representatives of COPES specifically to discuss proposed charges for Order/Billing and Subscription Services. 


\section{ACRL/AECT Joint Committee}

The Board approved the addition of $\$ 200$ to support the work of this joint committee, and that the representatives of the Association for Educational Communications and Technology on this committee be encouraged to approach AECT for comparable funding.

\section{Chapters}

The Board approved the "Budgetary Guidelines for ACRL Funds for Chapters" developed by the Budget and Finance Committee. These guidelines will appear in a future issue of Chapter Topics.

\section{Choice}

The Board approved the recommendation of the editor and publisher of Choice to select the H.W. Wilson Company as the vendor to automate Choice reviews through the Wilson electronic publishing system. Choice plans to develop specifications and modifications to the Wilson system this spring so that its September 1987 issue could be automated. Benefits to be derived from automation will include: the control of escalating personnel costs; increasing the timeliness of reviews; and creating a searchable database of reviews that will become a source of revenue for Choice.

Choice is also exploring a proposal by the R.R. Bowker Company to join in a project to publish a database of reviews on CD-ROM.

\section{College \& Research Libraries}

The Board approved the K.G. Saur Award for Best College \& Research Libraries Article and authorized the submission of the award proposal to the ALA Awards Committee.

\section{Discussion groups}

The Board approved the petition for the establishment of a Canadian Studies Discussion Group.

\section{Fiscal policy}

The Board approved two revisions to ACRL fiscal policy: that the ACRL Executive Director has the right to reimburse chapters, sections, and committees within certain limitations; and that only single copies of ACRL standards will be given away at no charge - a charge for multiple copies of standards will be determined by ACRL staff.

\section{Higher education}

The Board authorized the College Libraries Section to make available, by drawing on existing sources, relevant data on library costs as a component of higher education, specifically as a response to Secretary of Education William Bennett's recent remarks on the cost of higher education. The Section will write a draft press release and letter to Sec- retary Bennett, which then will be forwarded to ACRL Headquarters for action.

\section{Historically black institutions}

The Board approved submitting a "Proposal for a Planning Project to Assist Staff in Libraries of Historically Black Colleges and Universities" for funding to the Mellon Foundation, the Council on Library Resources, and other potential foundations.

\section{Hugh Atkinson resolution}

The Board adopted a memorial resolution on the late Hugh C. Atkinson. The resolution is reprinted in this issue on p.131.

The Board also approved a recommendation to appoint up to two members to serve on a joint task force with other interested ALA divisions to: 1) explore alternatives for commemorating the work of Hugh Atkinson; 2) explore financial possibilities with vendors and other potential supporters of such a project; and 3) make specific recommendations to each divisional board at Annual Conference in San Francisco.

\section{International relations}

The Board approved the establishment of a Task Force on International Relations with the following charge: to prepare guidelines for the promotion of exchanges of librarians between the U.S. and other countries; to promote the exchange of professional information, ideas, and literature between the U.S. and other countries; and to assist librarians of other countries in the use of library and bibliographic techniques.

\section{Legislation Committee}

The Board accepted the recommendation of the Planning Committee that the composition of the ACRL Legislation Committee be modified to specify at least one member from each type of library and that type-of-library sections be encouraged to appoint liaisons to the Legislation Committee.

The Board also endorsed a resolution prepared by the Legislation Committee on Higher Education Act Title II that encourages the appropriation of $\$ 30$ million in support of HEA programs in FY 1988. A resolution of the Rare Books and Manuscripts Section that was endorsed by the Legislation Committee was also approved by the Board, urging Congress to reject both the request for recission of FY 1987 funds for Title II-C and the zerobudgeting for this program in FY 1988.

\section{Library access}

The Board endorsed the report by the ACRL Task Force on Library Access, "Responses to Freedom and Equality of Access," and transmit it to the ALA Special Committee on Freedom and Equality of Access to Information. The Task Force's report 
reviews the recommendations of the Lacy Commission, annotates them briefly to express the interests of academic libraries, and provides suggestions for revisions in the text where appropriate.

\section{Model Statement}

The Board approved the ACRL "Model Statement of Criteria and Procedures for Appointment, Promotion in Academic Rank, and Tenure for College and University Librarians," as revised by the ACRL Standards and Accreditation Committee, and that the previous version be rescinded. The revised Model Statement will appear in a future issue of $C \mho R L N e w s$.

\section{National conference}

The Board approved the selection of Phoenix, Arizona, as the site for the April 1-4, 1992, ACRL National Conference.

\section{Output measures}

The Board authorized the ACRL Executive Director to contract with a specialist at a cost of no more than \$5,000 to work with the Ad Hoc Committee on Performance Measures to define clearly as many as twelve performance measures for academic libraries that could be developed into a writ-

\section{Recruitment open for editor of ACRL Publications in Librarianship}

ACRL's monographic series, ACRL Publications in Librarianship, will require a new editor to serve on a volunteer basis when Arthur Young completes his term of service. The incoming editor will serve as associate editor from September 1987 to June 1988 and will assume full editorship for a 5-year period in July 1988.

Besides ACRL membership, candidates should have a background of service in academic or research librarianship; experience in research, editing, and bibliographical activities; a concern with publication as a means of professional communication; and an ability to analyze manuscripts for content, research methods, form, structure, or style.

Together with the four- to six-member editorial board, the editor is charged with encouraging research and writing that may be appropriate for the monographic series, soliciting topics and suggesting them to appropriate authors, and editing and refereeing manuscripts.

Persons wishing to be considered for the fiveyear term as editor should communicate their interest, accompanied by a statement of qualifications and names of references, by May 1 , 1987, to: Charles B. Lowry, Director of Libraries, P.O. Box 19497, University of Texas, Arlington, TX 76019. ten manual. The specific measures might be used as the basis for an RFP to potential authors. The Board also requested that the Ad Hoc Committee report to the Board at Annual Conference in San Francisco, and that the issuing of a contract be dependent upon a review by the Budget and Finance Committee and the Board.

\section{Paper reduction}

The Board passed a proposal that the Executive Director look into the feasibility of reducing certain mailings to section chairs and report to the Board at Annual Conference in San Francisco.

\section{Professional ethics}

The Board approved the "Standards for Ethical Conduct for Rare Book, Manuscript, and Special Collections Libraries," developed by a Committee of the Rare Books and Manuscripts Section. These standards are published in this issue on pp.134-35.

\section{Professional Association Liaison Committee}

The Board accepted the recommendation of the Planning Committee that the following task be added to the Professional Liaison Association Committee charge: to coordinate the work of ACRL representatives to other organizations.

\section{Section newsletter policy}

The Board approved a revised version of the ACRL Policy on Section Newsletters and directed ACRL staff to send the revised policy to the sections for comment. The Board will review the comments on the policy at Annual Conference in San Francisco. The revised policy appears on pp.138-39 of this issue.

\section{Washington State University computing services project}

The Board voted to send a letter confirming the importance of a study being conducted at WSU on the organization and integration of library and computing services in the research university.

\section{Women's Studies Section}

The Board approved the Bylaws of the Women's Studies Section, which appear on pp.137-38 of this issue.

\section{This publication is available in microform from University Microfilms International.}

Call toll-free 800-521-3044. Or mail inquiry to: University Microfilms International, 300 North Zeeb Road, Ann Arbor, MI 48106. 